\title{
The Tumor Microenvironment in Neuroendocrine Tumors: Biology and Therapeutic Implications
}

\author{
Mauro Cives Eleonora Pelle' Davide Quaresmini Francesca Maria Rizzo \\ Marco Tucci Franco Silvestris \\ Department of Biomedical Sciences and Human Oncology, University of Bari "Aldo Moro", Bari, Italy
}

\section{Keywords}

Immune microenvironment · Programmed death-ligand

1 - Cancer-associated fibroblast - Carcinoid tumors .

Neoangiogenesis

\begin{abstract}
Neuroendocrine tumors (NETs) include a heterogeneous group of malignancies arising in the diffuse neuroendocrine system and characterized by indolent growth. Complex interactions take place among the cellular components of the microenvironment of these tumors, and the recognition of the molecular mediators of their interplay and cross talk is crucial to discover novel therapeutic targets. NET cells overexpress a plethora of proangiogenic molecules including vascular endothelial growth factor, platelet-derived growth factor, fibroblast growth factor, semaphorins, and angiopoietins that promote both recruitment and proliferation of endothelial cell precursors, thus resulting among the most vascularized cancers with a microvessel density 10 -fold higher than epithelial tumors. Also, NETs operate multifaceted interactions with stromal cells, both at local and distant sites, and whether their paracrine secretion of serotonin, connec-
\end{abstract}

\section{KARGER}

() 2019 S. Karger AG, Basel

E-Mail karger@karger.com

www.karger.com/nen tive tissue growth factor, and transforming growth factor $\beta$ primarily drives the fibroblast activation to enhance the tumor proliferation, on the other side NET-derived profibrotic factors accelerate the extracellular matrix remodeling and contribute to heart valves and/or mesenteric fibrosis development, namely, major complications of functioning NETs. However, at present, little is known on the immune landscape of NETs, but accumulating evidence shows that tumor-infiltrating neutrophils, mast cells, and/or macrophages concur to promote the neoangiogenic switch of these tumors by either direct or indirect mechanisms. On the other hand, immune checkpoint molecules are heterogeneously expressed in NETs' surrounding cells, and it is unclear whether or not tumor-infiltrating lymphocytes are antitumor armed within the microenvironment, given their low mutational load. Here, we review the current knowledge on both gastroenteropancreatic and pulmonary NETs' microenvironment as well as both established and innovative treatments aimed at targeting the tumor-host interplay.

(c) 2019 S. Karger AG, Basel

M.C. and E.P. contributed equally to this work.
Prof. Franco Silvestris

Department of Biomedical Sciences and Human Oncology

University of Bari "Aldo Moro"

Piazza Giulio Cesare, 11, IT-70124 Bari (Italy)

E-Mail francesco.silvestris@ uniba.it 


\section{Introduction}

Neuroendocrine tumors (NETs) are heterogenous malignancies arising in secretory cells of the diffuse neuroendocrine system. Although they may originate in almost any organ, NETs predominate within the gastroenteropancreatic (GEP) tract and the bronchopulmonary (BP) tree [1]. The incidence of NETs has steadily increased in the last 3 decades, and gastroenteropancreatic neuroendocrine tumors (GEP-NETs) currently represent the second most common digestive cancer in terms of prevalence [2]. NETs may present as either hormonally functioning or nonfunctioning tumors. While pancreatic neuroendocrine tumors (pNETs) may produce a variety of peptide hormones including insulin, glucagon, and gastrin, metastatic midgut NETs often secrete serotonin and other vasoactive substances, giving rise to the typical carcinoid syndrome, characterized by flushing, diarrhea, and right-sided valvular heart disease [1].

Impressive progress has been made in recent years in the understanding of both biology and molecular genetics of NETs. First, somatostatin receptors and their downstream pathways have been described as key regulators of proliferation, protein synthesis, and hormone secretion in NET cells. Second, aberrant activation of the mammalian target of rapamycin signaling has been discovered as hallmark of both GEP- and bronchopulmonary neuroendocrine tumors and significantly contributes to the tumor progression by improving survival, angiogenesis, and cell metabolism. Third, the tumor neoangiogenesis has been depicted as a crucial event in NET progression, and overexpression of proangiogenic factors including vascular endothelial growth factor (VEGF), fibroblast growth factor (FGF), and platelet-derived growth factor (PDGF) by NET cells has been reported [3].

Although considered in the past as insular masses of clonally proliferating cancer cells, all tumors are currently recognized as complex tissues including multiple heterogeneous cell types that variably interact by heterotypic cross talk within themselves and with the surrounding cell structures [4]. The so-called "tumor microenvironment" (TME), primarily constituted by supportive matrix, stromal cells, endothelial cells and inflammatory cells, promotes the tumor growth, modulates the tumor behavior, and influences the treatment response, thus contributing to epigenetic deregulations of cancer cells, acquisition of invasive and metastatic capabilities, as well as induction of both local and systemic immune suppression. Accumulating evidence suggests that the TME plays a pivotal role not only in the progression of NETs but also in the pathogenesis of their fibrotic complications. In this context, a dynamic cross talk between NET cells and reactive stroma regulates the growth and tumor progression, and intensive research is currently underway to therapeutically exploit the vulnerabilities of such a molecular interplay [5].

In this review, we provide an overview of the current knowledge on the biology and function of the TME in both GEP- and bronchopulmonary neuroendocrine tumors, focusing on the potential therapeutic applications of TME-targeting agents in NET patients.

\section{The Tumor Microenvironment}

Functional components of the TEM are next summarized.

\section{The Extracellular Matrix}

The extracellular matrix (ECM) is a key component of both normal and tumor tissues. It is constituted by a complex texture of cross-linked proteins contributing to structural organization, elasticity, hydration, and trophism of resident cells. The specific composition of the matrix strictly controls tissue biochemical and biomechanical properties, and peculiar ECM alterations have been described in NETs (Table 1).

A quantitative proteomic approach has been recently used to compare the composition of the ECM in normal pancreatic islets and their tumor counterparts using the RIP1-Tag2 murine insulinoma model, and 35 ECM proteins have been reported to be differentially expressed [6]. Among these, fibulin-3, periostin, fibrinogens, and kininogens were found to be significantly upregulated in insulinomas, while decorin, hemicentin-1, lectin, galectin-1, and mannose binding 1 were shown to be downregulated. Overall, these changes were associated with angiogenic switch and microvessel sprouting, namely, typical features of early insulinoma progression. By using a transgenic mouse model of $\beta$-cell carcinogenesis, Saupe et al. [7] have demonstrated that the ECM glycoprotein Tenascin-C has a crucial role in both early and late events of pNET tumorigenesis. In particular, this proteoglycan has been described to inhibit the formation of actin stress fibers in pNET cells, as well as to downregulate Dickkopf-1 and activate the Wnt signaling, thus promoting cell survival, angiogenic switch, and tumor progression.

Prominent alterations are usually observed in the ECM of small intestinal (SI) NETs, and the biologic un-
Cives/Pelle'/Quaresmini/Rizzo/Tucci/ Silvestris 
Table 1. ECM modifications in NETs: an overview

\begin{tabular}{|c|c|c|c|}
\hline $\begin{array}{l}\text { Tumor } \\
\text { location }\end{array}$ & $\begin{array}{l}\text { Experimental model } \\
\text { (analysis performed) }\end{array}$ & ECM alterations & Reference \\
\hline \multirow[t]{3}{*}{ pNETs } & $\begin{array}{l}\text { RIP1-Tag2 mouse (proteomic analysis } \\
\text { and IHC) }\end{array}$ & $\begin{array}{l}\text { Upregulation of Fibulin-3, Periostin, Fibrillin-1, Kininogen-1 } \\
\text { and -2, Fibrinogen- } \alpha,-\beta \text { and }-\gamma \\
\text { Downregulation of Decorin, Hemicentin-1, Annexin-a3, -a6, -a7, } \\
\text { and -a11, Cathepsin L, Galectin-1, Dmbt-1, von Willebrand factor } \\
\text { A domain-containing, Lectin mannose binding-1, Regenerating } \\
\text { islet-derived protein-1, -2 and -3g, Elastase Cela-1, -2a and -3b, } \\
\text { Trypsinogen Prss-1, -2, -and -3, Trypsin Try-4 and -10 }\end{array}$ & $\begin{array}{l}{[6]} \\
r\end{array}$ \\
\hline & $\begin{array}{l}\text { Rip-TNC mouse }+14 \text { human } \\
\text { insulinomas (gene expression analysis } \\
\text { and IHC) }\end{array}$ & Upregulation of TNC & {$[7]$} \\
\hline & $\begin{array}{l}\text { RIP1-Tag2 mouse }+150 \text { human pNETs } \\
\text { (gene expression analysis and IHC) }\end{array}$ & Upregulation of heparanase & {$[16]$} \\
\hline BP-NETs & 55 typical BP-NETs (IHC) & Upregulation of collagen and elastic fibers & {$[11]$} \\
\hline $\begin{array}{l}\text { GEP- and } \\
\text { BP-NETs }\end{array}$ & $\begin{array}{l}31 \text { GEP-NETs + } 8 \text { BP-NETs (RT-PCR } \\
\text { and IHC) }\end{array}$ & $\begin{array}{l}\text { Downregulation of Glyptan-1 and -5 in poorly differentiated } \\
\text { NETs } \\
\text { Downregulation of Syndecan-2 in well-differentiated NETs } \\
\text { Upregulation of UST and downregulation of CHST3 in poorly } \\
\text { differentiated NETs }\end{array}$ & {$[12]$} \\
\hline GEP-NETs & 162 GEP-NETs (IHC) & Upregulation of IMP3 & {$[19]$} \\
\hline
\end{tabular}

NET, neuroendocrine tumor; pNET, pancreatic neuroendocrine tumor; SI-NET, small intestinal neuroendocrine tumor; BP-NET, bronchopulmonary neuroendocrine tumor; GEP-NET, gastroenteropancreatic neuroendocrine tumor; IHC, immunohistochemistry; RT-PCR, real-time polymerase chain reaction; TNC, tenascin-C; MMP, matrix-metalloproteinase; VMAT-1, vesicular monoamine transporter 1; TIMP, tissue inhibitor of metalloproteinase; UST, uronyl 2-sulphotransferase; IMP3, insulin-like growth factor mRNAbinding protein 3 .

derpinnings of focal desmoplasia as a common feature of these tumors have been recently reviewed by Blažević et al. [8]. Of note, an abundant presence of collagen III fibers has been shown in small intestinal neuroendocrine tumors (SI-NETs), and myofibroblasts with an activated, synthetic phenotype have been diffusely observed within the TME of these malignancies $[9,10]$. Deregulation of a number of signaling molecules has been implicated in pathogenesis of carcinoid-related desmoplasia, and a crucial role has been attributed to profibrotic growth factors including serotonin, connective tissue growth factor (CTGF), transforming growth factor $\beta$ (TGF- $\beta$ ), PDGF, and FGF [8].

Little is known regarding the composition of the ECM in pulmonary NETs. In a histochemistry study of 55 typical lung NETs, a higher density of collagen and elastic fibers within the ECM were associated with increased tumor size and nodal metastases [11].

The extent of ECM remodeling has been described to be grade-dependent in NETs. A progressive accumulation of chondroitin sulfate has been observed in the ECM of 39 well- and poorly differentiated NETs, while a significant reduction of the proteoglycans Syndecan-2 and Glypican-1 has been demonstrated in poorly differentiated tumors as compared with well-differentiated NETs [12]. On the other hand, the upregulation of laminin- $\alpha 2$ in the basement membrane of intratumor capillaries was demonstrated to occur more frequently in small and large cell lung neuroendocrine cancers rather than in pulmonary carcinoids, and a role in transendothelial migration of neoplastic cells and metastasis was envisaged for this protein [13]. 


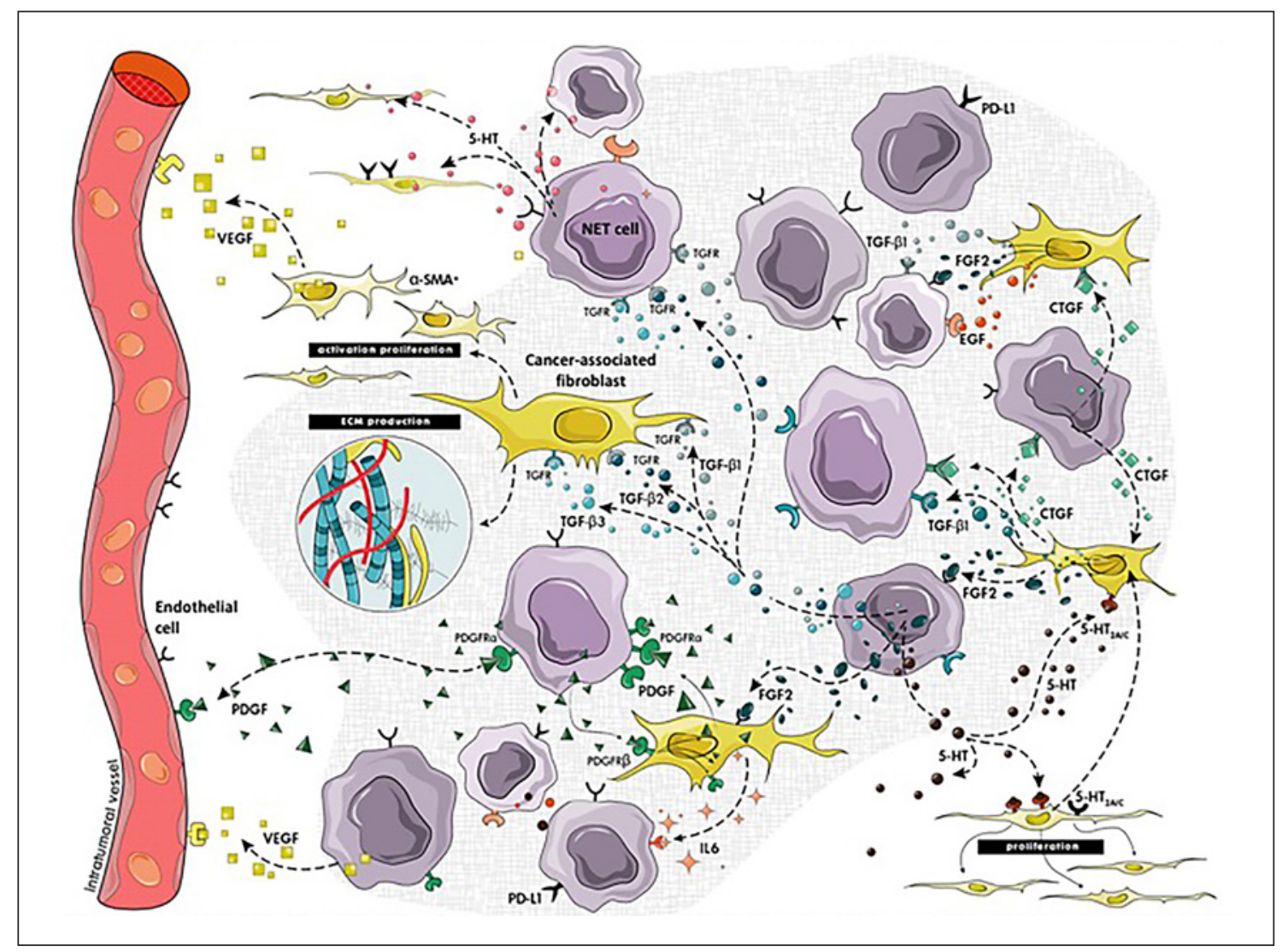

Fig. 1. Schematic overview of the cross talk between tumor cells, fibroblasts, and endothelial cells occurring within the TME. VEGF, vascular endothelial growth factor; $\alpha$-SMA, $\alpha$-smooth muscle actin; NET, neuroendocrine tumor; PD-L1, programmed death-ligand 1 ; TGF- $\beta$, transforming growth factor $\beta$; FGF, fibroblast growth factor; CTGF, connective tissue growth factor; CAF, cancer-associated fibroblast; PDGF, platelet-derived growth factor.

Dynamic modifications of the ECM in NETs have been attributed to 2 major protease families, namely, heparanases and matrix-metalloproteinases (MMPs). Heparanases are endo- $\beta$-glucuronidases that cleave the heparan-sulfate side chains of ECM glycoproteins resulting in matrix loosening as well as release of proangiogenic molecules and growth factors in the extracellular space [14]. Expression of heparanase has been reported to increase throughout the multistage progression of insulinomas using the Rip1-Tag2 murine model. Of interest, infiltrating $\mathrm{Gr} 1+/ \mathrm{Mac} 1+$ innate immune cells were described as the major source of this enzyme in the context of the tumors, and a definite role was demonstrated for heparanase in the mobilization of matrix-associated VEGF and neoangiogenesis [15]. Accordingly, high heparanase expression levels were shown to significantly correlate with advanced tumor stage, higher tumor grade, and presence of distant metastases in a series of 150 human pNETs [16]. In lung NETs, the overexpression of both heparanase and its antimetastatic homolog heparanase- 2 was found to be more frequent in well-differentiated carcinoids rather than in poorly differentiated ones [17]. MMPs belong to a family of zinc-dependent proteinases that are produced either as soluble or cell membrane-anchored enzymes and are capable to degrade the ECM with wide substrate specificity [14]. Several studies have reported the overexpression of MMP2 in GEP-NETs [18, 19], and both serum and urinary levels of this enzyme have been found elevated in patients with digestive NETs $[20,21]$. In a mouse model of pNET, MMP9 proved to be critically involved in tumor angiogenesis. However, the genetic silencing of this MMP led to increased tumor invasiveness as a result of enhanced production of cathepsin-B by tumor-infiltrating inflammatory cells [22]. Of note, the MMP Neprilysin has been recently shown to be the primary epigenetic target of the complex Menin/Daxx [23]. As inactivating mutations of both MEN1 and DAXX are frequently observed in pNETs, and the consequent over- 

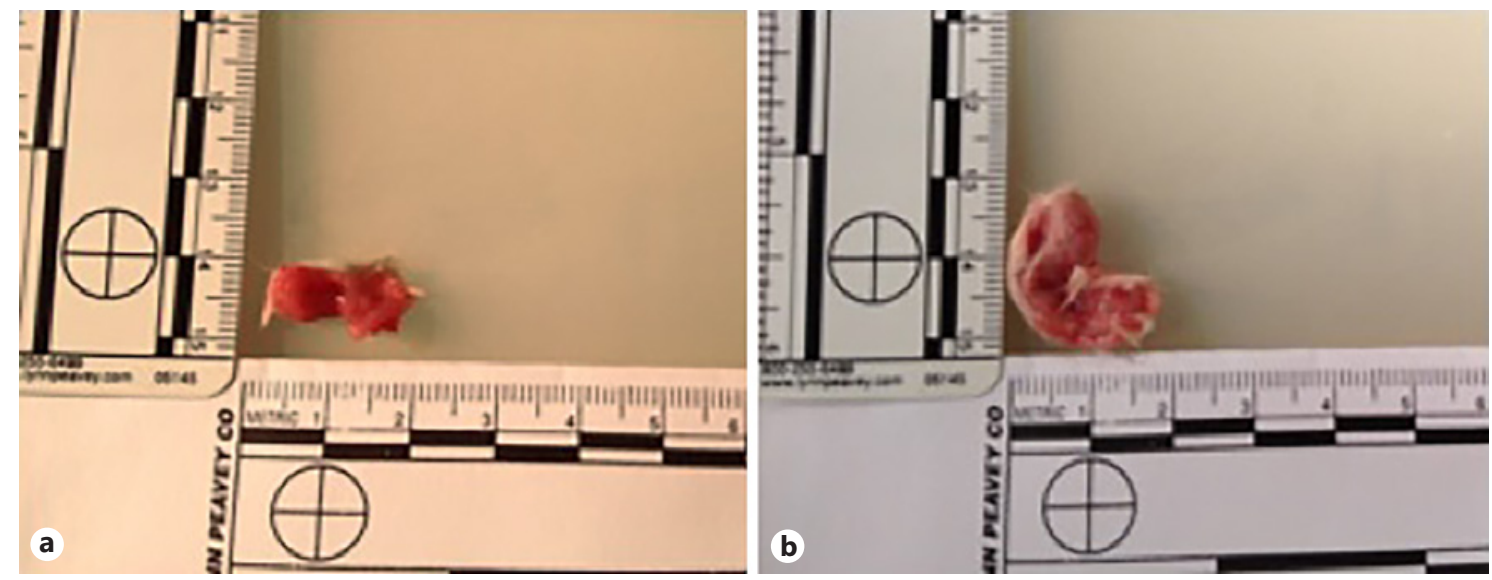

Fig. 2. CAFs stimulate the proliferation of NET cells in vivo. NOD/SCID mice were subcutaneously injected with $4 \times 106$ pNET CM cells in the absence $(\mathbf{a})$ or presence $(\mathbf{b})$ of $4 \times 105$ CAFs derived from a patient with pNET. After 4 weeks, tumors were excised and measured. Tumor volume was substantially higher in the group of mice coinjected with NET cells and $\alpha$-smooth muscle actin-positive fibroblasts [37].

expression of Neprilysin has been interpreted as a key event in the $\beta$-cell carcinogenic process.

Overall, ECM degradation contributes to NET development, progression, and aggressiveness through different mechanisms. First, fragmentation of ECM components generates chemoattractants that recruit inflammatory cells, thus creating a protumorigenic microenvironment. Second, proangiogenic factors are released in their bioactive form as a consequence of matrix remodeling. Third, as neuroendocrine cells are typically mechanosensitive changes in the ECM elasticity may influence tumor behavior. In this context, mechanical stress per se has been demonstrated to induce serotonin secretion in the pNET cell line BON1 as well as in the SI-NET cell line KRJ-I $[24,25]$. In the latter cellular model, the activation of the mechanoreceptor ADORA2B by extracellular adenosine has been demonstrated to play a pivotal role in regulating serotonin secretion, particularly under hypoxic conditions $[25,26]$.

\section{Stromal Cells}

Fibroblasts are major components of the TME, and their structural and functional contribution to the tumorigenesis of NETs has recently emerged. As represented in Figure 1, increasing evidence indicates that a cross talk exists between fibroblasts and NET cells, as well as between fibroblasts and endothelial cells or inflammatory cells. NET cells stimulate both proliferation and activation of fibroblasts by secreting a plethora of soluble factors, including serotonin, TGF- $\beta$, and PDGF. In coculture experiments using the SI-NET cell line KRJ-I and the fibroblast-like cell line HEK293, Svejda et al. [27] demon- strated that carcinoid-derived serotonin promotes fibroblast proliferation as well as synthesis of profibrotic factors such as CTGF, TGF- $\beta 1$, and FGF2 by activating the 5-HT2A/C receptor. Moreover, multiple studies [28-33] have shown that TGF- $\beta$ and its receptors are coexpressed in both tumor and stromal cells in NETs, and there is evidence that both TGF- $\beta 1,-\beta 2$, and $-\beta 3$ may drive the acquisition of a synthetic, $\alpha$-smooth muscle actin-positive phenotype in fibroblasts $[9,34,10]$. In a heterogeneous cohort of GEP-NETs, immunoreactivity for PDGF was detected on both tumor cells and stromal cells in 70\% of cases, while the expression of PDGF- $\alpha$ and $-\beta$ receptors was compartmentalized in tumor cells and fibroblasts, respectively. However, the expression of PDGFR- $\beta$ was considerably higher in stromal cells adjacent to the tumor rather than in fibroblasts distant from NET cells [30, 35]. Although in the absence of direct evidence from functional studies, these findings suggested that NET cells may induce the expression of PDGFR- $\beta$ in fibroblasts and then promote their proliferation and activation through paracrine and possibly autocrine mechanisms.

While the effects of NET cells on the reactive stroma have been well characterized, the modifications induced by cancer-associated fibroblasts (CAFs) to tumor cells still remain poorly understood. Evidence from our group and others $[36,37]$ indicates that CAFs may stimulate NET growth both in vitro and in vivo (Fig. 2), and that functional interactions between mesenchymal and neuroendocrine cells are influenced by tumor grade, with poorly differentiated neoplasms being less dependent on stromal cell support in their proliferation. Of interest, the 
proliferative capability of NET cells appears to be modulated only by activated, $\alpha$-smooth muscle actin-positive myofibroblasts and not by resting fibroblasts, and this protumorigenic effect seems to be mediated by paracrine mechanisms rather than cell-to-cell contact. In this context, Bowden et al. [38] have recently compared the secretome of NET-associated fibroblasts and normal human fibroblasts and found that IL-6, VEGF, and monocyte chemoattractant protein 1 are actively secreted by CAFs, thus envisaging a role for these cytokines as inducers of NET cell proliferation. Upon TGF- $\beta$ activation, fibroblasts secrete CTGF, and evidence suggests that this growth factor may regulate enterochromaffin-like cell proliferation and promote the development of gastrin carcinoids in the Mastomys natalensis animal model [39].

\section{Endothelial Cells}

NETs are among the most extensively vascularized cancers, with an intratumoral vessel density approximately 10 -fold higher as compared with carcinomas [40, 41]. This is not surprising, as a high vascular supply is required for the physiologic functions of normal endocrine tissue. In contrast with other epithelial neoplasms, the intratumoral microvascular density of pNETs is higher in low-grade rather than in high-grade tumors and appears to be associated with good prognosis and prolonged survival. Although the exact biologic significance of this phenomenon, named as "neuro-endocrine paradox" still needs to be elucidated, it has been hypothesized that most differentiated NET cells may retain the capability of their normal precursors to promote the formation of a dense vascular network in the TME, whereas neoangiogenesis of poorly differentiated neoplasms might be primarily driven by an angiogenic switch as effect of rapid cell proliferation and hypoxia [42].

As a result of the aberrant hyperactivation of the hypoxia-inducible factor- $1 \alpha$ transcriptional program, NET cells overexpress a plethora of proangiogenic factors including VEGF, FGF, PDGF, semaphorins, and angiopoietins [43]. VEGF is overexpressed in up to $80 \%$ of GEPNETs and is the main driver of tumor angiogenesis in these malignancies due to its positive effects on both endothelial cell proliferation and vascular permeability [4446]. Tumor expression of VEGF is higher in well-differentiated neoplasms with respect to poorly differentiated NETs $[41,45,47]$ and mirrors the expression of VEGFR-1 and VEGFR-2 on both tumor cells and endothelial cells [46]. Experiments using the RIP1-Tag2 mouse model have demonstrated that VEGF has a crucial role throughout the whole course of the multistage process of pancre- atic islets tumorigenesis, particularly in the transition from $\beta$-cell hyperplasia to neuroendocrine neoplasia [47]. In fact, $\beta$ cell-specific knockout of VEGF in RIP1-Tag2 mice resulted in decreased angiogenic switch and neovasculature formation in dysplastic islets, thus preventing both formation and growth of pNETs [48]. However, tumor cells are not the only source of VEGF in pNETs, and tumor-infiltrating neutrophils have been recently shown to mobilize latent VEGF from the ECM through the secretion of MMP-9 [49].

In contrast with pNETs, the role of VEGF has been poorly studied in midgut and pulmonary NETs, and contradictory results have been provided regarding the correlation between expression of this growth factor, microvascular density, and patient prognosis [42]. In KRJ-I midgut carcinoid cells, VEGF expression has been demonstrated to be strictly modulated by oxygen levels through a pathway regulated by hypoxia-inducible factor$1 \alpha$ [50]. Moreover, the pool of adenosine released in the TME under hypoxic conditions has been described as a critical regulator of the proliferation of KRJ-I cells through the activation of ADORA2A and/or ADORA2B receptors $[26,51]$.

A second proangiogenic circuit regulating pNET progression involves FGF and its cognate receptors. FGF directly promotes endothelial proliferation and migration as well as vessel formation and maturation, while concurrently modulating the production of other proangiogenic molecules by both tumor and stromal cells. Of note, the FGF/FGFR axis has been demonstrated as one of the key driver of VEGF-independent revascularization of pNETs, a phenomenon occurring after evasive resistance to antiangiogenic therapy [52]. Overexpression of PDGF and PDGFR- $\beta$ has both proangiogenic and protumorigenic effects in NETs. Indeed, while the degree of expression of PDGFR- $\beta$ closely parallels the microvascular density, the paracrine secretion of the PDGF-DD isoform by endothelial cells has been shown to positively regulate NET cell proliferation $[35,53]$.

Semaphorins are a family of glycoproteins involved in vascular and nervous system formation and have shown dual pro- and antiangiogenic effects in NETs. Semaphorins act through their interaction with the neuropilin receptors that have been found to be overexpressed in gut neuroendocrine cells and pNETs, but not in midgut carcinoids [54, 54]. Experiments in RIP1-Tag2 mice have demonstrated that endothelial expression of semaphorin 3A (SEMA3A) is progressively lost during tumor progression and that pharmacological inhibition of SEMA3A during the angiogenic switch of dysplastic islets may en-
88

Neuroendocrinology 2019;109:83-99 DOI: $10.1159 / 000497355$
Cives/Pelle'/Quaresmini/Rizzo/Tucci/ Silvestris 
hance angiogenesis and tumor formation. Interestingly, reexpression of SEMA3A by viral gene transfer during late stage of pancreatic endocrine carcinogenesis has the potential to normalize tumor vasculature, increase pericyte coverage, and inhibit tumor progression $[56,57]$. Similar antiangiogenic properties have been described for SEMA3F in ileal NETs [58]. In contrast with SEMA3A and SEMA3F, expression of SEMA5A has demonstrated a detrimental effect in pNET, where this transmembrane semaphorin stimulates angiogenesis, tumor growth, invasion, and metastases [59].

Angiopoietins have been recently described as major drivers of NET progression. In this context, angiopoietin- 2 has been found to be significantly upregulated in pNETs [60], and in vivo evidence has demonstrated the ability of this molecule in increasing the microvascular density of pNET xenografts [61]. The upregulation of angiopoietin-2 and its cognate receptor TIE-2 is a distinctive feature of pNETs developing resistance to VEGF blockade, and experiments in RIP1-Tag2 mice have shown that TIE-2+ myeloid cells recruited within angiopoietin-expressing insulinomas have proangiogenic potential, thus contributing to tumor progression $[62,63]$.

As in other cancers, the vascular alterations observed in NETs are not only quantitative but also qualitative. Indeed, tumor-associated vessels are characterized by fenestrated endothelial cells with large intercellular spaces, discontinuous basement membrane, and lack of pericyte coverage. A cross-talk exists between endothelial cells and pericytes, and evidence indicates that the latter cell type may induce an autocrine VEGF prosurvival signaling in endothelial cells, thus promoting neovascular formation [64].

\section{Immune Cells}

The immune contexture of NETs has become clearer in recent years. A plethora of immune cells including B and T cells, NK cells, mast cells, dendritic cells, as well as macrophages have been reported to infiltrate NETs, thus creating an immunosuppressed microenvironment permissive for the tumor progression. Overall, infiltration of immune cells appears to be higher in pNETs rather than in midgut carcinoids, possibly as consequence of the higher mutational burden of pNETs [65]. In a series of 87 pNETs, T cell infiltration was detectable in $68 \%$ of samples and was not associated with tumor grade or other clinicopathological variables. However, as the vast majority of patients with liver metastases $(97 \%)$ had some degree of $\mathrm{CD} 3+$ infiltration, a progressive activation of the immune system during tumor progression and mutation accumulation was envisaged. Consistently, in patients with intermediate-grade pNETs, low-density infiltration of CD3 + T cells significantly predicted recurrence following tumor resection [66].

In a cohort of $102 \mathrm{G} 1 / \mathrm{G} 2$ primary small bowel NETs, an intratumor host immune response was observed in approximately two-thirds of cases, and the extent of the inflammatory infiltration was described as significantly higher in duodenal NETs as compared with jejunal or ileal carcinoids. Intriguingly, about one-fifth of the tumors showed ectopic lymph nodes with activated germinal centers, but the biologic significance of these tertiary lymphoid structures in NETs is still unclear [67]. In another study of 62 patients with SI NET, infiltration of CD8+ lymphocytes was observed in $97 \%$ of samples, but was only focal in $93 \%$ of cases [68]. Of note, lymphoid aggregates were found in $27 \%$ of tumors. Surprisingly, levels of immune infiltration seem to compare similarly in well and poorly differentiated digestive NETs, in spite of the striking differences in the mutational burden of these tumor entities. In fact, in a small cohort of 37 high-grade GEP neuroendocrine carcinomas (NECs), the presence of programmed death-1 (PD-1)-positive lymphocytes was observed in $63 \%$ of cases [69].

Both low- and high-grade pulmonary NETs have been shown to be infiltrated by CD8+ lymphocytes, and the presence of a dense infiltrate has been reported as an independent predictor of improved overall survival and progression-free survival (PFS) [70].

$\mathrm{CD} 4+$ FoxP3 + T regulatory (Treg) cells have a crucial role not only in the maintenance of immunological selftolerance in physiological conditions but may also act as pivotal drivers of immune evasion in cancer patients. Presence of immunosuppressive FoxP3+ cells has been described as predominant in high- versus low-grade pNETs and independently predicts poor prognosis [66, 71]. Preliminary results from a multicolor flow-cytometry analysis of 31 samples of midgut NET have demonstrated that Treg are more abundant in tumors as compared with matched normal tissue, with a CD8+/FoxP3+ ratio of 18 and 24, respectively [72]. Irrespective of tumor infiltration, circulating levels of Treg cells are significantly higher in patients with midgut carcinoid as compared with healthy subjects, and the frequency of circulating FoxP3+ cells appears to parallel the tumor load. In this context, the lower proliferative capability of $\mathrm{T}$ cells derived from patients with midgut NETs rather than from normal controls has been associated with a Treg-driven suppression of systemic Th1-promoting cytokines such as IL- $1 \beta$ and IL-12 p70 [73]. 
Table 2. PD-L1 expression in GEP- and BP-NETs

\begin{tabular}{|c|c|c|c|c|c|c|}
\hline Tumor location & Samples (tumor grade), $n$ & $\begin{array}{l}\text { Metastatic } \\
\text { cases, } \%\end{array}$ & $\begin{array}{l}\text { Anti-PD-L1 } \\
\text { mAb used }\end{array}$ & $\begin{array}{l}\text { Cutoff used for } \\
\text { interpretation of } \\
\text { positive staining }\end{array}$ & Positive samples, \% & Reference \\
\hline $\begin{array}{l}\text { GEP-NETs } \\
14 \text { pancreas } \\
8 \text { colon-rectum } \\
7 \text { biliary tract } \\
2 \text { duodenum } \\
1 \text { stomach }\end{array}$ & $32(15 \mathrm{G} 2 ; 17 \mathrm{G} 3)$ & 100 & Clone SP142 & $1 \%$ of tumor cells & $22 \%$ (G3 tumors: $41 \%$ ) & {$[86]$} \\
\hline $\begin{array}{l}\text { GEP-NETs } \\
48 \text { small intestine } \\
62 \text { pancreas }\end{array}$ & $\begin{array}{l}116^{\#}(66 \mathrm{G} 1,34 \mathrm{G} 2,4 \mathrm{G} 3,6 \\
\text { unknown) }\end{array}$ & 36 & $\begin{array}{l}\text { Clone SP142 } \\
\text { Clone 28-8 } \\
\text { Clone 22C3 }\end{array}$ & $5 \%$ of tumor cells & $\begin{array}{l}6 \%(\text { clone SP142) } \\
0 \% \text { (clones } 28-8 \text { or } 22 \mathrm{C} 3 \text { ) }\end{array}$ & {$[87]$} \\
\hline $\begin{array}{l}\text { GEP-NETs } \\
128 \text { small intestine } \\
72 \text { pancreas } \\
26 \text { colon-rectum } \\
17 \text { esophagus/stomach } \\
1 \text { biliary tract }\end{array}$ & $244^{*}(141 \mathrm{G} 1,83 \mathrm{G} 2,20 \mathrm{G} 3)$ & 43 & Clone E1L3N & $1 \%$ of tumor cells & $\begin{array}{l}\text { 9\% (G1/G2 tumors: } 8 \% \text {; G3 } \\
\text { tumors: } 17 \% \text { ) } \\
\text { (pNETs: } 18 \% \text {; non-pancreatic } \\
\text { NETs: } 7 \% \text { ) }\end{array}$ & {$[88]$} \\
\hline $\begin{array}{l}\text { GEP-NETs } \\
16 \text { small bowel } \\
10 \text { pancreas } \\
10 \text { stomach } \\
10 \text { liver } \\
7 \text { colon } \\
2 \text { biliary tract } \\
2 \text { others }\end{array}$ & 57 (39 G1; 9 G2; 9 G3) & 4 & Clone E1L3N & $10 \%$ of tumor cells & $\begin{array}{l}28 \% \text { (G1 tumors: } 0 \% \text {; G2 } \\
\text { tumors: } 78 \% \text {; G3 tumors: 100\%) }\end{array}$ & {$[89]$} \\
\hline $\begin{array}{l}\text { GEP-NETs } \\
64 \text { small bowel } \\
31 \text { pancreatic }\end{array}$ & 95 & 4 & Clone 9A11 & $5 \%$ of tumor cells & $\begin{array}{l}\text { SI-NETs: } 0 \% \\
\text { pNETs: } 7 \%\end{array}$ & {$[65]$} \\
\hline $\begin{array}{l}\text { GEP-NECs } \\
18 \text { colon-rectum } \\
6 \text { biliary tract } \\
3 \text { pancreas } \\
3 \text { oesophagus } \\
3 \text { stomach } \\
1 \text { small bowel } \\
1 \text { duodenum }\end{array}$ & 37 (37 G3) & 49 & Clone E1L3N & $1 \%$ of tumor cells & $14 \%$ & {$[69]$} \\
\hline $\begin{array}{l}\text { SI-NETs } \\
89 \text { small bowel } \\
10 \text { duodenum } \\
3 \text { unknown }\end{array}$ & $102(94$ G1; 8 G2) & 54 & Clone 28-8 & $\begin{array}{l}1 \% \text { of tumor cells; } \\
5 \% \text { of tumor cells; } \\
50 \% \text { of tumor cells }\end{array}$ & $\begin{array}{l}39 \% \text { ( } 1 \text { and } 5 \% \text { cut-off }) \\
14 \%(50 \% \text { cut-off) }\end{array}$ & {$[67]$} \\
\hline SI-NETs & $70(47 \mathrm{G} 1 ; 23 \mathrm{G} 2)$ & 55 & Clone E1L3N & $5 \%$ of tumor cells & $13 \%$ & {$[68]$} \\
\hline pNETs & 117 & Unknown & Clone E1L3N & $5 \%$ of tumor cells & $42 \%$ & {$[90]$} \\
\hline pNETs & 70 & 68 & Clone SP142 & $\begin{array}{l}5 \% \text { of tumor cells } \\
1 \% \text { of tumor cells }\end{array}$ & $\begin{array}{l}3 \%(5 \% \text { cut-off }) \\
11 \%(1 \% \text { cut-off })\end{array}$ & [93] \\
\hline BP-NETs & $80(22$ G1/G2; 58 G3) & 41 & Clone 28-8 & $5 \%$ of tumor cells & $59 \%$ & {$[91]$} \\
\hline LC-NECs & 95 & 3 & Clone E1L3N & $1 \%$ of tumor cells & $74 \%$ & {$[92]$} \\
\hline
\end{tabular}

* PD-L1 analyzed in 215 cases.

\# From 110 unique patients.

GEP-NET, gastroenteropancreatic neuroendocrine tumor; SI-NET, small intestinal neuroendocrine tumor; pNET, pancreatic neuroendocrine tumor; BP-NET, bronchopulmonary neuroendocrine tumor; LC-NEC, large cell neuroendocrine carcinoma; PD-L1, programmed death-ligand 1. 


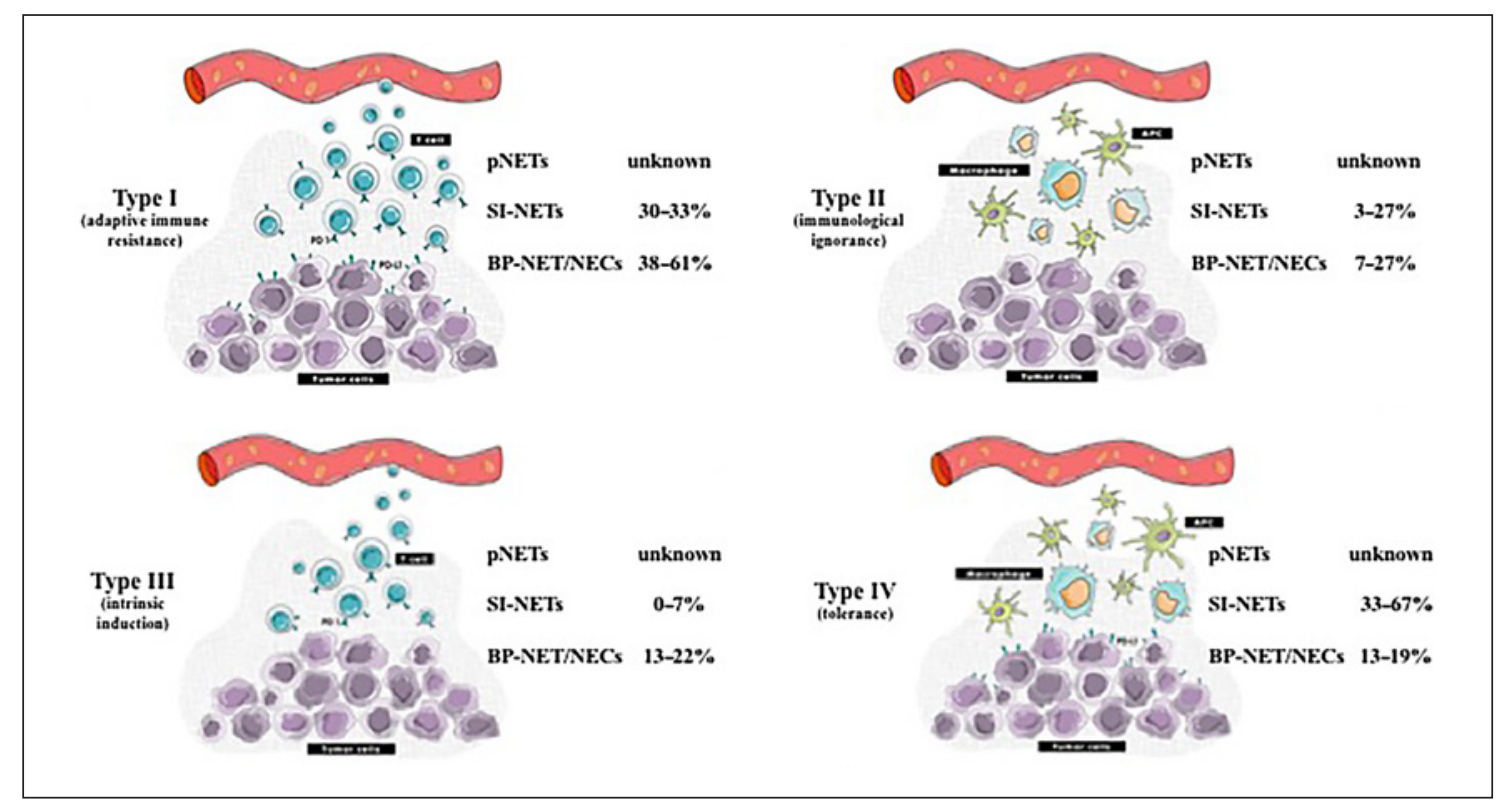

Fig. 3. Schematic representation of the 4 subgroups of immune microenvironment [94] most commonly observed in NETs based on available evidence $[67,68,91,92]$. Type I (adaptive immune resistance): PD-L1+, TILs+; type II (immunological ignorance): PD-L1-, TIL-; type III (intrinsic induction): PD-L1+, TIL-; type IV (tolerance): PD-L1-, TIL+. NET, neuroendocrine tumor; pNET, pancreatic neuroendocrine tumor.

NK cells have demonstrated impaired cytolytic activity in GEP-NET patients. In particular, NK cell activity has been related to disease status, decreasing and increasing in patients progressing or responding to therapies, respectively [74]. Remarkably, a deficient IFN- $\alpha$ response has been observed in patients with midgut carcinoids, but NK cell activity could be restored by exogenous IFN treatment [75]. Tumor-infiltrating mast cells have been reported to orchestrate a complex inflammatory and angiogenic response during pNET progression. In this context, pharmacological inhibition of mast cells degranulation in mice harboring islet-cell tumors proved effective in inducing extensive cell death of tumor and associated endothelial cells, leading to cancer regression $[76,77]$.

Both local and systemic derangements of dendritic cell activity have been described in NETs. An altered expression of MHC class I molecules including $\beta 2$-microglobulin has been demonstrated in 10/11 samples of pNETs and could hinder antigen presentation to dendritic cells [78]. In addition, carcinoid-specific soluble immune inhibitory factors have been found to modulate both maturation and function of dendritic cells, and immunohistochemical analysis revealed the complete absence of CD1a+ and CD83+ infiltrating dendritic cells in bronchial NETs, while the generation of dendritic cells from umbilical cord CD34+ precursors was completely abro- gated by cell-free supernatants from bronchial NET cells [79]. Tumor-associated macrophages (TAM) have been detected in both primary and metastatic NETs. The highest degree of TAM infiltration has been found in poorly rather than in well-differentiated neoplasms, as well as in liver metastases rather than in primary tumors or metastatic lymph nodes [80]. In pNETs, the number of TAM was shown to correlate with tumor grade and presence of liver metastases, and evidence from murine models demonstrates that macrophages contribute to both angiogenic switch and pNET progression [80,81]. In a study of 97 pNETs, the degree of TAM infiltration revealed predictive recurrence after surgery, especially in patients lacking other clinicopathological features of tumor malignancy [82].

NET patients display immune recognition of their tumors. CD8+ T cells targeting specific NET-associated antigens including chromogranin A and tryptophan hydroxylase have been documented in patients with midgut carcinoids, and reactive memory $\mathrm{T}$ cells have been found in approximately $15 \%$ of patients with small bowel NETs [83]. Despite the presence of both tumor infiltration and recognition, NET cells are capable to evade the control of the immune system [84]. In this context, immunomodulatory factors including CD45, CD53, CD86, IL2RB1, IL10, CIITA, and RUNX3 have been recently identified as master regulators of the GEP-NET 
metastatic progression and may have a key role in promoting tumor immune escape [85]. This is consistent with the emerging concept that the neuroendocrine system can be regarded as a subsidiary extension of the innate immune system, or that NET cells may derive from immunosuppressive mesenchymal stem cell-like neuroendocrine precursors. Multiple studies have investigated so far the expression of the immune checkpoint molecule programmed death-ligand 1 (PD-L1) as an additional mechanism of NET immune evasion [65, 67-69, 86-93]. As shown in Table 2, the upregulation of PD-L1 has been observed in a minority of NETs, although a certain degree of heterogeneity is evident across studies. Differences in the clinical characteristics of enrolled patients (i.e., primary site, grade, fraction of metastatic cases) as well as discrepancies in both the mAb clone used for PD-L1 detection and the criteria employed for staining interpretation may account, at least partly, for such interstudy heterogeneity.

The main characteristics of the immune landscape of NETs are depicted in Figure 3 according to the model developed by Teng et al. [94] on the basis of both tumor immune infiltration and PD-L1 expression. Overall, mechanisms different from adaptive immune resistance (as defined by the presence of both high PD-L1 expression and dense lymphocyte infiltrate) seem to be primarily involved in the local immune suppression occurring within the TME of NETs, thus suggesting that only a minority of these malignancies may be effectively targeted with immune checkpoint inhibitors, at least theoretically.

\section{Targeting the TME in NETs}

Interfering with the interactions between tumor cells and reactive components of the TME is a promising strategy to improve the outcomes of NET patients. Numerous antiangiogenic agents have been investigated in NETs, and the VEGFR inhibitor sunitinib has been approved for the treatment of pNETs. Oral inhibitors of the serotonin synthesis pathway have been developed, and their antifibrotic and antiproliferative activities should be assessed. Investigations of immunotherapeutic agents in patients with NETs are currently underway, and preliminary results emphasize the importance of patient preselection based on tumor biology (i.e., PD-L1 expression, tumor immune infiltration, mutational load). Established and future clinical applications of TME-targeting agents are discussed in this section.

\section{Antiangiogenic Agents}

In NETs, angiogenesis is primarily regulated by VEGF. The VEGF signaling can be blocked at different levels, including direct VEGF inhibition (i.e., bevacizumab, aflibercept) as well as VEGFR suppression by either tyrosine kinase inhibitors (TKI; i.e., sunitinib, pazopanib, axitinib) or $\mathrm{mAb}$ (i.e., ramucirumab). Bevacizumab is a humanized $\mathrm{mAb}$ against VEGF and has been investigated in both pancreatic and gastrointestinal NETs. In a phase II study of 44 patients with carcinoid tumors, bevacizumab was associated with better PFS as compared with pegylated IFN- [95]. However, no benefit in terms of PFS has been recently recorded in a phase III trial comparing bevacizumab plus octreotide versus IFN plus octreotide in 427 patients with carcinoid tumors, thus suggesting that the 2 drugs have similar efficacy in advanced NETs [96].

The oral TKI sunitinib targets PDGFR, c-kit, and the subtypes 1, 2, and 3 of VEGFR. The drug was investigated in a double-blind, placebo-controlled, phase III trial of 171 patients with low-to-intermediate grade progressive pNETs, showing a significant improvement of PFS in the sunitinib arm (11.1 vs. 5.5 months; hazard ratio: $0.42, p<0.001$ ) [97]. On this basis, the drug was approved for advanced, progressive pNETs. Circulating levels of VEGFR3, IL-8, and CXCL12 have been shown to predict the efficacy of sunitinib in patients with pNETs [98]. Pazopanib, another TKI targeting VEGFR-1, -2, and -3 , has been investigated in combination with octreotide in a phase II study of 52 patients with pancreatic or non-pNETs. The drug demonstrated activity only in the pNET cohort, where the rate of objective responses and the median PFS were $22 \%$ and 14.4 months, respectively [99]. In another phase II study enrolling 44 patients with advanced pancreatic, gastrointestinal, or thoracic NETs who progressed on a prior line of systemic therapy, pazopanib was associated with a median PFS of 9.5 months [100]. Axitinib is a selective inhibitor of VEGFR-1, -2 , and -3 and has been tested in a heterogeneous population of 30 patients with low-to-intermediate, advanced NETs. The drug showed activity in inhibiting tumor growth, and a median PFS of 26.7 months was recorded although the treatment was associated with a $63 \%$ rate of grade $3 / 4$ hypertension [101]. A randomized phase II/III trial is currently comparing axitinib plus octreotide LAR versus placebo plus octreotide LAR in 253 patients with G1/G2 NETs of nonpancreatic origin (NCT01744249). Ramucirumab, a IgG1 mAb against VEGFR2, is being currently investigated in a phase II study of non-pNETs (NCT02795858).
Cives/Pelle'/Quaresmini/Rizzo/Tucci/ Silvestris 
Hyperactivation of the FGF/FGFR signaling is a hallmark of NETs that become resistant to anti-VEGF therapies. Nintedanib is a dual inhibitor of VEGFR-1, -2, and -3 as well as FGFR-2 and showed both antiangiogenic and antitumor activity in the RIP1-Tag2 transgenic mouse model of pNET tumorigenesis [102]. A phase II clinical trial is currently evaluating the efficacy of the drug in patients with G1/G2 non-pNETs (NCT02399215). Brivanib has a pharmacodynamic profile similar to that of nintedanib and has demonstrated antitumor activity in pNETs in in vivo experiments [52]. Lenvatinib is an oral inhibitor of VEGFR, FGFR, PDGFRa, RET, and KIT. The phase II TALENT study (NCT02678780) is evaluating the efficacy of the drug in patients with either gastrointestinal NETs progressing to somatostatin analog or pNET progressing after targeted therapy. Accrual has been completed and preliminary results are awaited soon. The VEGFR, FGFR, and CSF1R inhibitor sulfatinib has shown encouraging antitumor activity in a phase I study [103]. On this basis, the drug is being currently investigated in 2 separate phase III trials enrolling patients with pancreatic and extrapancreatic NETs, respectively (NCT02589821 and NCT02588170). Cabozantinib is a TKI-inhibiting c-met, VEGFR2, AXL, and RET and showed preclinical activity against NETs [104]. The drug has been recently investigated in a 2-cohort, phase II trial enrolling 61 patients with progressive pancreatic or non-pNETs, with encouraging preliminary results. In fact, median PFS of 21.8 and 31.4 months were achieved in the pNET and carcinoid cohort, respectively [105]. Based on these results, a double-blind, randomized, phase III trial has been initiated and is comparing cabozantinib versus placebo in patients with NET who progressed on everolimus (NCT03375320).

As described above, mast cells and macrophages infiltrating NETs have both proangiogenic and protumorigenic potential. Ibrutinib, an oral inhibitor of Bruton's tyrosine kinase, is capable to suppress the degranulation of mast cells, thus leading to vascular collapse and tumor regression in animal models of pNETs [77]. A phase II study is currently investigating the efficacy of the drug in patients with carcinoid tumors and pNETs (NCT02575300). The angiopoietin receptor Tie-2 is frequently expressed by TAMs, and the administration of the Tie-2 inhibitor rebastinib in orthotopic models of pNETs has resulted in reduced vascular density and permeability as well as diminished metastatic spread [106]. In RIP1-Tag2 mice, liposomal clodronate was able to reduce TAM infiltration, thereby leading to decreased microvessel density and tumor regression [80]. Clinical investigations of TAM-targeting agents are warranted in NET patients. Table 3 provides an overview of ongoing clinical trials of TME-targeting drugs, including antiangiogenic agents.

\section{Hypoxia-Activated Prodrugs}

Tumor hypoxia is the result of the deranged vasculature typical of NETs. Evofosfamide is a prodrug of the alkylating agent bromoisophosphoramide mustard, whose release from the original compound occurs only under hypoxic conditions. The active drug acts as a DNA cross-linking agent, inducing intra- and inter-strand cross links. The phase II SUNEVO study is currently assessing evofosfamide in combination with sunitinib in 43 patients with advanced, G1/G2, progressive pNETs (NCT02402062), and results are awaited soon.

\section{Inhibitors of Serotonin Production}

Serotonin has a pivotal role in inducing fibroblast activation, leading to both local and distant fibrosis in patients with NET. Telotristat ethyl is an orally bioavailable inhibitor of tryptophan hydroxylase, and has been recently approved for the palliation of diarrhea in patients with inadequately controlled carcinoid syndrome [107]. To date, neither there is no evidence that telotristat may inhibit tumor growth by interfering with the cross talk between tumor cells and fibroblasts nor there is proof of its activity in preventing mesenteric fibrosis or carcinoid heart disease as common NET-related complications. Evaluation of the antiproliferative effect of telotristat in future clinical trials of patients with NET is warranted.

\section{Immune Checkpoint Inhibitors}

Immunotherapy has recently modified the cancer treatment approach, and efforts are currently underway to explore the efficacy of immune checkpoint inhibitors in patients with NETs. Expression of PD-L1, lymphocyte infiltration, mismatch repair deficiency, and consequently, tumor mutational, and neoantigen load have been depicted as major predictors of response to immune checkpoint blockade. On this basis, well-differentiated NETs appear suboptimal candidates for immunotherapy, at least theoretically. Indeed, levels of PD-L1 vary widely across published studies (Table 2), suggesting that expression of this protein is heterogeneous in G1/G2 NETs. Lymphocyte infiltration is commonly observed in these tumors, but it is unclear whether TILs are effectively primed by tumor neoantigens, given the relatively low proportion of cases positive for PD-1. Moreover, most NETs appear to be mismatch repair proficient, and the mutational burden of such malignancies is relatively 
Table 3. Ongoing clinical trials of TME-targeting agents in GEP and BP-NETs

\begin{tabular}{|c|c|c|c|c|c|c|c|}
\hline Therapeutic regimen & Main molecular target(s) & $\begin{array}{l}\text { Clinical } \\
\text { phase }\end{array}$ & Patient population & $\begin{array}{l}\text { Sample } \\
\text { size }\end{array}$ & $\begin{array}{l}\text { Primary } \\
\text { outcome }\end{array}$ & $\begin{array}{l}\text { Estimated } \\
\text { Completion date }\end{array}$ & Identifier \\
\hline $\begin{array}{l}\text { Axitinib }+ \text { Sandostatin } \\
\text { LAR vs. Placebo }+ \\
\text { Sandostatin LAR }\end{array}$ & VEGFR 1-3 & $\mathrm{II} / \mathrm{III}$ & Advanced, progressive, G1/G2 NETs of nonpancreatic origin & 253 & PFS & October 2020 & NCT01744249 \\
\hline $\begin{array}{l}\text { Pazopanib }+ \\
\text { temozolomide }\end{array}$ & VEGFR $1-3$, PDGFR- $\alpha$ and $-\beta, c-K I T$ & $\mathrm{I} / \mathrm{II}$ & Advanced pNETs & 39 & MTD & August 2020 & NCT01465659 \\
\hline Pazopanib & VEGFR $1-3$, PDGFR- $\alpha$ and $-\beta, c-K I T$ & II & Progressive, nonpancreatic G1/G2 NETs & 165 & PFS & July 2018 & NCT01841736 \\
\hline Nindetanib & $\begin{array}{l}\text { VEGFR 1-3, PDGFR- } \alpha \text { and }-\beta \text {, FGFR } 1-3 \text {, } \\
\text { FLT3, SRC }\end{array}$ & II & Advanced, G1/G2 NETs of nonpancreatic origin & 30 & PFS & March 2019 & NCT02399215 \\
\hline Cabozantinib & $\begin{array}{l}\text { c-MET, VEGFR2, AXL, KIT, TIE2, FLT3, } \\
\text { RET }\end{array}$ & II & Unresectable G1/G2, carcinoid or pNET & 62 & ORR & April 2022 & NCT01466036 \\
\hline Cabozantinib & $\begin{array}{l}\text { c-MET, VEGFR2, AXL, KIT, TIE2, FLT3, } \\
\text { RET }\end{array}$ & III & Advanced NETs after progression on Everolimus & 395 & PFS & January 2021 & NCT03375320 \\
\hline Lenvatinib & $\begin{array}{l}\text { VEGFR 1-3, FGFR 1-4, PDGFR } \alpha \text {, RET, } \\
\text { KIT }\end{array}$ & II & $\begin{array}{l}\text { Advanced pNETs after progression to a targeted agent or } \\
\text { gastrointestinal NET after progression to somatostatin } \\
\text { analogs }\end{array}$ & 111 & ORR & December 2017 & NCT02678780 \\
\hline Sulfatinib & VEGFR 1-3, FGFR1, CSF1R & III & Advanced, G1/G2, extrapancreatic NETs & 273 & PFS & June 2019 & NCT02588170 \\
\hline Sulfatinib & VEGFR 1-3, FGFR1, CSF1R & III & Advanced, G1/G2 pNETs & 195 & PFS & September 2018 & NCT02589821 \\
\hline Sulfatinib & VEGFR 1-3, FGFR1, CSF1R & $\mathrm{Ib}$ & $\begin{array}{l}\text { Advanced, G1/G2 NETs who have failed standard treatment } \\
\text { or are unable to receive standard treatment }\end{array}$ & 81 & Safety & August 2017 & NCT02267967 \\
\hline Famitinib & c-Kit, VEGFR2-3, PDGFR, FLT1, FLT3 & II & Advanced, G1/G2 GEP-NETs & 53 & ORR & May 2016 & NCT01994213 \\
\hline Regorafenib & VEGFR 1-3, PDGFR $\beta$, KIT, RET, RAF-1 & II & Advanced, progressive carcinoid or pNET & 48 & PFS & August 2020 & NCT02259725 \\
\hline Anlotinib & $\begin{array}{l}\text { VEGFR2/3, FGFR1-4, PDGFR- } \alpha \text { and }-\beta \text {, } \\
\text { c-KIT, RET }\end{array}$ & II & G3 advanced GEP-NETs & 60 & PFS & August 2019 & NCT03457844 \\
\hline Ibrutinib & BTK & II & Advanced, G1/G2 carcinoid or pNETs & 51 & ORR & December 2019 & NCT02575300 \\
\hline Avelumab & $\mathrm{PD}-\mathrm{L} 1$ & II & Advanced, G2/G3, WD NETs & 36 & ORR & September 2021 & NCT03278379 \\
\hline Avelumab & PD-L1 & II & Advanced GEP-NECs progressive to etoposide+cisplatin & 30 & $\begin{array}{l}\text { Best } \\
\text { response }\end{array}$ & February 2020 & NCT03147404 \\
\hline Avelumab & PD-L1 & II & Advanced NEC progressive after first-line chemotherapy & 60 & DCR & January 2024 & NCT03352934 \\
\hline Avelumab & PD-L1 & $\mathrm{I} / \mathrm{II}$ & Advanced GEP- or BP-NEC & 10 & ORR & September 2020 & NCT03278405 \\
\hline $\begin{array}{l}\text { Durvalumab }+ \\
\text { tremelimumab }\end{array}$ & PD-L1 + CTLA-4 & II & $\begin{array}{l}\text { Advanced, G1/G2 GEP- or BP-NETs and G3 GEP-NETs } \\
\text { progressive to previous therapies }\end{array}$ & 126 & $\begin{array}{l}\text { Clinical } \\
\text { Benefit Rate }\end{array}$ & March 2020 & NCT03095274 \\
\hline JS001 & PD-1 & $\mathrm{Ib}$ & $\begin{array}{l}\text { Advanced, nonfunctioning NETs with a Ki- } 67 \geq 10 \% \text { progres- } \\
\text { sive to first-line therapy }\end{array}$ & 40 & ORR & October 2018 & NCT03167853 \\
\hline $\begin{array}{l}\text { Nivolumab + } \\
\text { Ipilimumab }\end{array}$ & PD-1 + CTLA-4 & II & $\begin{array}{l}\text { Advanced, progressive, WD, nonfunctioning GEP- or } \\
\text { BP-NETs }\end{array}$ & 64 & ORR & January 2024 & NCT03420521 \\
\hline Spartalizumab & PD-1 & II & $\begin{array}{l}\text { Advanced, WD, nonfunctioning GEP or BP-NETs or } \\
\text { GEP-NECs progressive to prior treatment }\end{array}$ & 110 & ORR & December 2019 & NCT02955069 \\
\hline Pembrolizumab & PD-1 & II & Recurrent NECs & 40 & ORR & September 2022 & NCT03190213 \\
\hline Pembrolizumab & PD-1 & II & $\begin{array}{l}\text { Metastatic G3 NET progressive to platinum-based chemo- } \\
\text { therapy }\end{array}$ & 21 & ORR & January 2020 & NCT02939651 \\
\hline $\begin{array}{l}\text { Pembrolizumab alone } \\
\text { or with chemotherapy } \\
\text { (paclitaxel or irinotecan) }\end{array}$ & PD-1 & II & Previously treated extrapulmonary NECs & 42 & ORR & June 2020 & NCT03136055 \\
\hline Pembrolizumab & PD-1 & II & Advanced NECs and/or G3 NETs & 30 & ORR & December 2021 & NCT03290079 \\
\hline $\begin{array}{l}\text { Pembrolizumab }+ \\
\text { Lanreotide Depot }\end{array}$ & PD-1 & $\mathrm{Ib} / \mathrm{II}$ & $\begin{array}{l}\text { Advanced, recurrent, or metastatic well or moderately } \\
\text { differentiated GEP-NETs }\end{array}$ & 26 & ORR & June 2020 & NCT03043664 \\
\hline $\begin{array}{l}\text { Evofosfamide (TH-302) } \\
+ \text { Sunitinib }\end{array}$ & $\begin{array}{l}\text { DNA + VEGFR-1-3, PDGFR- } \alpha \text { and }-\beta \text {, } \\
\text { c-KIT, FLT-3, CSF1R }\end{array}$ & II & Advanced, G1/G2, treatment-naïve pNETs & 43 & ORR & June 2019 & NCT02402062 \\
\hline
\end{tabular}

AXL, AXL receptor tyrosine kinase; BTK, bruton tyrosine kinase; c-FMS, colony-stimulating factor-1 receptor; c-KIT, V-Kit hardy-zuckerman 4 feline sarcoma viral oncogene homolog; c-MET, MET protooncogene, receptor tyrosine kinase; CSF1R, colony-stimulating factor 1 receptor; CTLA-4, cytotoxic T-lymphocyte-associated protein 4; DCR, disease control rate; FGFR, fibroblast growth factor receptor; FLT3, Fms-related tyrosine kinase 3; MTD, maximum tolerated dose; ORR, overall response rate; PD, poorly differentiated; PDGFR, platelet-derived growth factor receptor; PD-1, programmed cell death 1; PD-L1, Programmed death-ligand 1; PFS, progression-free survival; RAF, v-raf murine sarcoma viral oncogene homolog B1; RET, Ret proto-oncogene; SRC, SRC proto-oncogene, nonreceptor tyrosine kinase; TIE2, tyrosine kinase with immunoglobulin and epidermal growth factor homology domains 2; VEGFR, vascular endothelial growth factor receptor. 
low, as only $3 \%$ of pNETs harbor $>17$ mutations $/ \mathrm{Mb}$, a cutoff usually used to predict response to immunotherapy [93]. In contrast, given their extensive mutational load and dense immune infiltration, NECs seem to represent suitable targets for immunotherapy [108].

Pembrolizumab, a mAb targeting PD-1, has been recently investigated in the phase Ib KEYNOTE-028 study. The trial enrolled 16 and 25 patients with heavily pretreated, PD-L1+ pancreatic and extrapancreatic NETs, respectively. Based on preliminary data, objective responses were observed in 12 and $6 \%$ of the carcinoid and pNET cohorts, respectively, while the 1-year PFS rate was $27 \%$ for either subgroups [109]. Similar results have been recently reported in a study of 110 patients with G1/G2 GEP- and lung NETs as well as GEP-NECs treated with spartalizumab (PDR-001), another inhibitor of PD-1 [110]. Ongoing phase II trials of immunotherapy in NETs are summarized in Table 3. Of interest, the oncolytic adenovirus AdVince, which selectively replicates within NET cells, is being currently investigated in a phase I/II study of patients with NETs [111]. It is currently unknown whether prior treatment with chemotherapy or peptide receptor radiotherapy may enhance the efficacy of immunotherapy in NETs.

Immune checkpoint inhibitors have shown promising results in NECs, either alone or in combination with chemotherapy. In a retrospective series of 10 patients with advanced pulmonary large-cell NEC, the anti-PD-1 mAbs nivolumab or pembrolizumab-induced partial responses in 6 subjects and were associated with a median PFS of approximately 14 months [112]. A double-blind, placebocontrolled, phase III study has recently investigated the combination of platinum-based chemotherapy with or without atezolizumab, an anti-PD-L1 mAb, in 403 patients with extensive, treatment-naïve small cell lung cancer. The addition of atezolizumab to the chemotherapy resulted in a significant increase in terms of both PFS (hazard ratio $0.77,95 \%$ CI $0.62-0.96 ; p=0.02$ ) and overall survival (hazard ratio $0.70,95 \%$ CI $0.54-0.91 ; p=0.007$ ) [113]. At present, very little is known regarding the efficacy of anti-PD1/ PD-L1 or anti-CTLA4 agents in GEP-NECs $[114,115]$.

\section{Conclusions}

Our understanding of the biology of NETs has improved substantially in the last decade, resulting in a considerable expansion of the treatment landscape of this heterogeneous group of tumors. In this context, the elucidation of the multifaceted interactions between tumor cells and their microenvironment has provided the basis for the rational design of successful clinical trials, paving the way to patient outcomes amelioration. Despite such progress, a number of key questions remain unanswered. What is the role of the TME in the development of treatment resistance in NETs? What are the changes induced by the TME to distant organs during the formation of the premetastatic niche in NETs? Is there any relationship between the TME and the epigenetic modifications characteristically observed in NETs? Can we exploit TME-derived circulating molecules to monitor patient outcomes? How can we further dissect (and target) the interactions between tumor cells and their TME? Future research is required to address these issues, among others.

\section{Acknowledgment}

Authors thank Lucrezia Alemanno for editorial assistance.

\section{Statement of Ethics}

The authors have no ethical conflicts to disclose.

\section{Disclosure Statement}

The authors have no conflicts of interest to declare.

\section{Funding Sources}

This work was supported by Associazione Italiana per la Ricerca sul Cancro (AIRC; grant number \#17536), Regione Puglia (Oncogenomic Project and Jonico-Salentino Project), and European NeuroEndocrine Tumor Society (ENETS; Excellence Academy Fellowship Grant 2016).

\section{Author Contributions}

M.C., E.P., and F.S. have contributed to the design of the work. M.C., E.P., D.Q., F.M.R., and M.T. have contributed to write the manuscript. F.S. critically reviewed the manuscript.

\section{References}

1 Cives M, Strosberg J. An update on gastroenteropancreatic neuroendocrine tumors. Oncology (Williston Park). 2014 Sep;28(9):749-56.

2 Yao JC, Hassan M, Phan A, Dagohoy C, Leary C, Mares JE, et al. One hundred years after "carcinoid": epidemiology of and prognostic factors for neuroendocrine tumors in 35,825 cases in the United States. J Clin Oncol. 2008 Jun;26(18):3063-72. 
3 Cives M, Strosberg J. Gastroenteropancreatic neuroendocrine tumors. CA Cancer J Clin. 2018 Nov;68(6):471-87.

4 Hanahan D, Weinberg RA. Hallmarks of cancer: the next generation. Cell. 2011 Mar; 144(5):646-74.

5 Laskaratos FM, Rombouts K, Caplin M, Toumpanakis C, Thirlwell C, Mandair D. Neuroendocrine tumors and fibrosis: an unsolved mystery? Cancer. 2017 Dec;123(24): 4770-90.

6 Naba A, Clauser KR, Mani DR, Carr SA, Hynes RO. Quantitative proteomic profiling of the extracellular matrix of pancreatic islets during the angiogenic switch and insulinoma progression. Sci Rep. 2017 Jan;7(1): 40495.

7 Saupe F, Schwenzer A, Jia Y, Gasser I, Spenlé $\mathrm{C}$, Langlois B, et al. Tenascin-C downregulates wnt inhibitor dickkopf-1, promoting tumorigenesis in a neuroendocrine tumor model. Cell Rep. 2013 Oct;5(2):482-92.

8 Blažević A, Hofland J, Hofland LJ, Feelders RA, de Herder WW. Small intestinal neuroendocrine tumours and fibrosis: an entangled conundrum. Endocr Relat Cancer. 2018 Mar; 25(3):R115-30.

9 Kidd M, Modlin I, Shapiro M, Camp R, Mane $\mathrm{S}$, Usinger $\mathrm{W}$, et al. CTGF, intestinal stellate cells and carcinoid fibrogenesis. World J Gastroenterol. 2007 Oct;13(39):5208-16.

10 Cunningham JL, Tsolakis AV, Jacobson A, Janson ET. Connective tissue growth factor expression in endocrine tumors is associated with high stromal expression of alpha-smooth muscle actin. Eur J Endocrinol. 2010 Oct; 163(4):691-7.

11 das Neves Pereira JC, da Silva AG, Soares F, Ab'Saber AM, Schmidt A, Rodrigues OR, et al. Nuclear and environment morphometric profile in tumor size and nodal metastasis of resected typical pulmonary carcinoid. Pathol Res Pract. 2004;200(6):459-67.

12 García-Suárez O, García B, Fernández-Vega I, Astudillo A, Quirós LM. Neuroendocrine tumors show altered expression of chondroitin sulfate, glypican 1 , glypican 5 , and syndecan 2 depending on their differentiation grade. Front Oncol. 2014 Feb;4:15.

13 Vitolo D, Ciocci L, Deriu G, Spinelli S, Cortese S, Masuelli L, et al. Laminin alpha2 chainpositive vessels and epidermal growth factor in lung neuroendocrine carcinoma: a model of a novel cooperative role of laminin-2 and epidermal growth factor in vessel neoplastic invasion and metastasis. Am J Pathol. 2006 Mar;168(3):991-1003.

14 Bonnans C, Chou J, Werb Z. Remodelling the extracellular matrix in development and disease. Nat Rev Mol Cell Biol. 2014 Dec;15(12): 786-801.

15 Joyce JA, Freeman C, Meyer-Morse N, Parish CR, Hanahan D. A functional heparan sulfate mimetic implicates both heparanase and heparan sulfate in tumor angiogenesis and invasion in a mouse model of multistage cancer. Oncogene. 2005 Jun;24(25):4037-51.
16 Hunter KE, Palermo C, Kester JC, Simpson K, Li JP, Tang LH, et al. Heparanase promotes lymphangiogenesis and tumor invasion in pancreatic neuroendocrine tumors. Oncogene. 2014 Apr;33(14):1799-808.

17 García B, García-Suárez O, Fernández-Vega I, Vallina A, Astudillo A, Quirós LM. Heparanase and heparanase 2 display differently deregulation in neuroendocrine tumors, depending on their differentiation grade. Histol Histopathol. 2016 Jan;31(1):73-81.

18 Voland P, Besig S, Rad R, Braun T, Baur DM, Perren A, et al. Correlation of matrix metalloproteinases and tissue inhibitors of matrix metalloproteinase expression in ileal carcinoids, lymph nodes and liver metastasis with prognosis and survival. Neuroendocrinology. 2009;89(1):66-78.

19 Er LM, Li Y, Wu ML, Zhao Q, Tan BB, Wang $\mathrm{XL}$, et al. Expression of IMP3 as a marker for predicting poor outcome in gastroenteropancreatic neuroendocrine neoplasms. Oncol Lett. 2017 Apr;13(4):2391-6.

20 Blicharz-Dorniak J, Kos-Kudła B, Foltyn W, Kajdaniuk D, Marek B, Zemczak A, et al. Is determination of matrix metalloproteinases and their tissue inhibitors serum concentrations useful in patients with gastroenteropancreatic and bronchopulmonary neuroendocrine neoplasms? Endokrynol Pol. 2012; 63(6):470-6.

21 Roy R, Zurakowski D, Wischhusen J, Frauenhoffer C, Hooshmand S, Kulke M, et al. Urinary TIMP-1 and MMP-2 levels detect the presence of pancreatic malignancies. $\mathrm{Br} \mathrm{J}$ Cancer. 2014 Oct;111(9):1772-9.

22 Shchors K, Nozawa H, Xu J, Rostker F, Swigart-Brown L, Evan G, et al. Increased invasiveness of MMP-9-deficient tumors in two mouse models of neuroendocrine tumorigenesis. Oncogene. 2013 Jan;32(4):502-13.

23 Feng Z, Wang L, Sun Y, Jiang Z, Domsic J, An C, et al. Menin and Daxx Interact to Suppress Neuroendocrine Tumors through Epigenetic Control of the Membrane MetalloEndopeptidase. Cancer Res. 2017 Jan;77(2): 401-11.

24 Linan-Rico A, Ochoa-Cortes F, Beyder A, Soghomonyan S, Zuleta-Alarcon A, Coppola $\mathrm{V}$, et al. Mechanosensory Signaling in Enterochromaffin Cells and 5-HT Release: Potential Implications for Gut Inflammation. Front Neurosci. 2016 Dec;10:564.

25 Chin A, Svejda B, Gustafsson BI, Granlund AB, Sandvik AK, Timberlake A, et al. The role of mechanical forces and adenosine in the regulation of intestinal enterochromaffin cell serotonin secretion. Am J Physiol Gastrointest Liver Physiol. 2012 Feb;302(3):G397405.

26 Dammen R, Haugen M, Svejda B, Alaimo D, Brenna O, Pfragner R, et al. The stimulatory adenosine receptor ADORA2B regulates serotonin (5-HT) synthesis and release in oxygen-depleted EC cells in inflammatory bowel disease. PLoS One. 2013 Apr; 8(4):e62607.
27 Svejda B, Kidd M, Giovinazzo F, Eltawil K, Gustafsson BI, Pfragner R, et al. The 5-HT(2B) receptor plays a key regulatory role in both neuroendocrine tumor cell proliferation and the modulation of the fibroblast component of the neoplastic microenvironment. Cancer. 2010 Jun;116(12): 2902-12.

28 Chaudhry A, Oberg K, Gobl A, Heldin CH, Funa K. Expression of transforming growth factors beta 1 , beta 2 , beta 3 in neuroendocrine tumors of the digestive system. Anticancer Res. 1994 Sep-Oct;14 5B:2085-91.

29 Gilbert JA, Adhikari LJ, Lloyd RV, Halfdanarson TR, Muders MH, Ames MM. Molecular markers for novel therapeutic strategies in pancreatic endocrine tumors. Pancreas. 2013 Apr;42(3):411-21.

30 Wulbrand U, Wied M, Zöfel P, Göke B, Arnold R, Fehmann H. Growth factor receptor expression in human gastroenteropancreatic neuroendocrine tumours. Eur J Clin Invest. 1998 Dec;28(12):1038-49.

31 Chaudhry A, Funa K, Oberg K. Expression of growth factor peptides and their receptors in neuroendocrine tumors of the digestive system. Acta Oncol. 1993;32(2):107-14.

32 Wimmel A, Wiedenmann B, Rosewicz S. Autocrine growth inhibition by transforming growth factor beta-1 (TGFbeta-1) in human neuroendocrine tumour cells. Gut. 2003 Sep; 52(9):1308-16.

33 Cives M, Rizzo F, Simone V, Bisceglia F, Stucci S, Seeber A, et al. Reviewing the Osteotropism in Neuroendocrine Tumors: The Role of Epithelial-Mesenchymal Transition. Neuroendocrinology. 2016;103(3-4):32134.

34 Beauchamp RD, Coffey RJ Jr, Lyons RM, Perkett EA, Townsend CM Jr, Moses HL. Human carcinoid cell production of paracrine growth factors that can stimulate fibroblast and endothelial cell growth. Cancer Res. 1991 Oct;51(19): 5253-60.

35 Funa K, Papanicolaou V, Juhlin C, Rastad J, Akerström G, Heldin CH, et al. Expression of platelet-derived growth factor beta-receptors on stromal tissue cells in human carcinoid tumors. Cancer Res. 1990 Feb;50(3): 748-53.

36 Dumortier J, Ratineau C, Scoazec JY, Pourreyron C, Anderson W, Jacquier MF, et al. Site-specific epithelial-mesenchymal interactions in digestive neuroendocrine tumors. An experimental in vivo and in vitro study. Am J Pathol. 2000 Feb;156(2):67183.

37 Cives M, Simone V, Rizzo FM, Bisceglia F, Vecchio M, Silvestris F. Cancer-associatedfibroblasts in neuroendocrine neoplasms: a role in cancer progression. Neuroendocrinology. 2014;99:231.

38 Bowden M, Sicinska E, Kulke M, Loda M. Understanding the role of the carcinoid associated fibroblast in neuroendocrine tumors microenvironment. Cancer Res. 2014;74(19 Suppl):Abstract 168. 
39 Kidd M, Modlin IM, Eick GN, Camp RL, Mane SM. Role of CCN2/CTGF in the proliferation of Mastomys enterochromaffin-like cells and gastric carcinoid development. Am J Physiol Gastrointest Liver Physiol. 2007 Jan; 292(1):G191-200.

40 Marion-Audibert AM, Barel C, Gouysse G, Dumortier J, Pilleul F, Pourreyron C, et al. Low microvessel density is an unfavorable histoprognostic factor in pancreatic endocrine tumors. Gastroenterology. 2003 Oct; 125(4):1094-104.

41 Couvelard A, O’Toole D, Turley H, Leek R, Sauvanet A, Degott C, et al. Microvascular density and hypoxia-inducible factor pathway in pancreatic endocrine tumours: negative correlation of microvascular density and VEGF expression with tumour progression. Br J Cancer. 2005 Jan;92(1):94101.

42 Scoazec JY. Angiogenesis in neuroendocrine tumors: therapeutic applications. Neuroendocrinology. 2013;97(1):45-56.

43 Carrasco P, Zuazo-Gaztelu I, Casanovas O. Sprouting strategies and dead ends in antiangiogenic targeting of NETs. J Mol Endocrinol. 2017 Jul;59(1):R77-91.

44 Kuroda M, Oka T, Oka Y, Yamochi T, Ohtsubo K, Mori S, et al. Colocalization of vascular endothelial growth factor (vascular permeability factor) and insulin in pancreatic islet cells. J Clin Endocrinol Metab. 1995 Nov; 80(11):3196-200.

45 Terris B, Scoazec JY, Rubbia L, Bregeaud L, Pepper MS, Ruszniewski P, et al. Expression of vascular endothelial growth factor in digestive neuroendocrine tumours. Histopathology. 1998 Feb;32(2):133-8.

46 La Rosa S, Uccella S, Finzi G, Albarello L, Sessa F, Capella C. Localization of vascular endothelial growth factor and its receptors in digestive endocrine tumors: correlation with microvessel density and clinicopathologic features. Hum Pathol. 2003 Jan;34(1): 18-27.

47 Besig S, Voland P, Baur DM, Perren A, Prinz C. Vascular endothelial growth factors, angiogenesis, and survival in human ileal enterochromaffin cell carcinoids. Neuroendocrinology. 2009;90(4):402-15.

48 Inoue M, Hager JH, Ferrara N, Gerber HP, Hanahan D. VEGF-A has a critical, nonredundant role in angiogenic switching and pancreatic beta cell carcinogenesis. Cancer Cell. 2002 Mar;1(2):193-202.

49 Nozawa H, Chiu C, Hanahan D. Infiltrating neutrophils mediate the initial angiogenic switch in a mouse model of multistage carcinogenesis. Proc Natl Acad Sci USA. 2006 Aug; 103(33):12493-8.

50 Haugen M, Dammen R, Svejda B, Gustafsson BI, Pfragner R, Modlin I, et al. Differential signal pathway activation and $5-\mathrm{HT}$ function: the role of gut enterochromaffin cells as oxygen sensors. Am J Physiol Gastrointest Liver Physiol. 2012 Nov; 303(10):G1164-73.
51 Kalhan A, Gharibi B, Vazquez M, Jasani B, Neal J, Kidd M, et al. Adenosine A2A and A2B receptor expression in neuroendocrine tumours: potential targets for therapy. Purinergic Signal. 2012 Jun;8(2):265-74.

52 Allen E, Walters IB, Hanahan D. Brivanib, a dual FGF/VEGF inhibitor, is active both first and second line against mouse pancreatic neuroendocrine tumors developing adaptive/evasive resistance to VEGF inhibition. Clin Cancer Res. 2011 Aug; 17(16):5299310.

53 Cortez E, Gladh H, Braun S, Bocci M, Cordero E, Björkström NK, et al. Functional malignant cell heterogeneity in pancreatic neuroendocrine tumors revealed by targeting of PDGF-DD. Proc Natl Acad Sci USA. 2016 Feb;113(7):E864-73.

54 Cohen T, Herzog Y, Brodzky A, Greenson JK, Eldar S, Gluzman-Poltorak Z, et al. Neuropilin-2 is a novel marker expressed in pancreatic islet cells and endocrine pancreatic tumours. J Pathol. 2002 Sep;198(1):77-82.

55 Cohen T, Gluzman-Poltorak Z, Brodzky A, Meytal V, Sabo E, Misselevich I, et al. Neuroendocrine cells along the digestive tract express neuropilin-2. Biochem Biophys Res Commun. 2001 Jun;284(2):395-403.

56 Maione F, Molla F, Meda C, Latini R, Zentilin $\mathrm{L}$, Giacca $\mathrm{M}$, et al. Semaphorin $3 \mathrm{~A}$ is an endogenous angiogenesis inhibitor that blocks tumor growth and normalizes tumor vasculature in transgenic mouse models. J Clin Invest. 2009 Nov;119(11):3356-72.

57 Maione F, Capano S, Regano D, Zentilin L, Giacca M, Casanovas O, et al. Semaphorin 3A overcomes cancer hypoxia and metastatic dissemination induced by antiangiogenic treatment in mice. J Clin Invest. 2012 May;122(5): 1832-48.

58 Bollard J, Massoma P, Vercherat C, Blanc M, Lepinasse F, Gadot N, et al. The axon guidance molecule semaphorin $3 \mathrm{~F}$ is a negative regulator of tumor progression and proliferation in ileal neuroendocrine tumors. Oncotarget. 2015 Nov;6(34):36731-45.

59 Saxena S, Hayashi Y, Wu L, Awaji M, Atri P, Varney ML, et al. Pathological and functional significance of Semaphorin-5A in pancreatic cancer progression and metastasis. Oncotarget. 2017 Dec;9(5):5931-43.

60 Durkin AJ, Bloomston M, Yeatman TJ, Gilbert-Barness E, Cojita D, Rosemurgy AS, et al. Differential expression of the Tie-2 receptor and its ligands in human pancreatic tumors. J Am Coll Surg. 2004 Nov;199(5):724-31.

61 Detjen KM, Rieke S, Deters A, Schulz P, Rexin A, Vollmer S, et al. Angiopoietin-2 promotes disease progression of neuroendocrine tumors. Clin Cancer Res. 2010 Jan;16(2):4209.

62 Mazzieri R, Pucci F, Moi D, Zonari E, Ranghetti A, Berti A, et al. Targeting the ANG2/ TIE2 axis inhibits tumor growth and metastasis by impairing angiogenesis and disabling rebounds of proangiogenic myeloid cells. Cancer Cell. 2011 Apr;19(4):512-26.
63 Rigamonti N, Kadioglu E, Keklikoglou I, Wyser Rmili C, Leow CC, De Palma M. Role of angiopoietin-2 in adaptive tumor resistance to VEGF signaling blockade. Cell Rep. 2014 Aug;8(3):696-706.

64 Franco M, Roswall P, Cortez E, Hanahan D, Pietras K. Pericytes promote endothelial cell survival through induction of autocrine VEGF-A signaling and Bcl-w expression. Blood. 2011 Sep;118(10):2906-17.

65 da Silva A, Bowden M, Zhang S, Masugi Y, Thorner AR, Herbert ZT, et al. Characterization of the Neuroendocrine Tumor Immune Microenvironment. Pancreas. 2018 Oct; 47(9):1123-9.

66 Katz SC, Donkor C, Glasgow K, Pillarisetty VG, Gönen M, Espat NJ, et al. T cell infiltrate and outcome following resection of intermediate-grade primary neuroendocrine tumours and liver metastases. HPB (Oxford). 2010 Dec;12(10):674-83.

67 Cives M, Strosberg J, Al Diffhala S, Coppola $\mathrm{D}$. Analysis of the immune landscape of small bowel neuroendocrine tumors. Endocr Relat Cancer. 2019 Jan 1;26(1):11930.

68 Lamarca A, Nonaka D, Breitwieser W, Ashton G, Barriuso J, McNamara MG, et al. PDL1 expression and presence of TILs in small intestinal neuroendocrine tumours. Oncotarget. 2018 Feb;9(19):14922-38.

69 Roberts JA, Gonzalez RS, Das S, Berlin J, Shi C. Expression of PD-1 and PD-L1 in poorly differentiated neuroendocrine carcinomas of the digestive system: a potential target for anti-PD-1/PD-L1 therapy. Hum Pathol. 2017 Dec;70:49-54.

70 Wang H, Li Z, Dong B, Sun W, Yang X, Liu R, et al. Prognostic significance of PD-L1 expression and CD8+ T cell infiltration in pulmonary neuroendocrine tumors. Diagn Pathol. 2018 May;13(1):30.

71 de Reuver PR, Mehta S, Gill P, Andrici J, D'Urso L, Clarkson A, et al. Immunoregulatory Forkhead Box Protein p3-Positive Lymphocytes Are Associated with Overall Survival in Patients with Pancreatic Neuroendocrine Tumors. J Am Coll Surg. 2016 Mar; 222(3):281-7.

72 Vesely C, Childs A, Wong YN, Ogunbiyi O, Gander A, Luong TV, et al. Systematic Evaluation of the Immune Microenvironment of Neuroendocrine Tumors (NET). In 15th Annual ENETS Conference 2018

73 Vikman S, Sommaggio R, De La Torre M, Oberg K, Essand M, Giandomenico V, et al. Midgut carcinoid patients display increased numbers of regulatory $\mathrm{T}$ cells in peripheral blood with infiltration into tumor tissue. Acta Oncol. 2009;48(3):391-400

74 Aparicio-Pagés MN, Verspaget HW, Peña AS, Jansen JB, Lamers CB. Natural killer cell activity in patients with neuroendocrine tumours of the gastrointestinal tract; relation with circulating gastrointestinal hormones. Neuropeptides. 1991 Sep;20(1): 1-7. 
75 Funa K, Alm GV, Rönnblom L, Oberg K. Evaluation of the natural killer cell-interferon system in patients with mid-gut carcinoid tumours treated with leucocyte interferon. Clin Exp Immunol. 1983 Sep; 53(3):716-24.

76 Soucek L, Lawlor ER, Soto D, Shchors K, Swigart LB, Evan GI. Mast cells are required for angiogenesis and macroscopic expansion of Myc-induced pancreatic islet tumors. Nat Med. 2007 Oct;13(10):1211-8.

77 Soucek L, Buggy JJ, Kortlever R, Adimoolam S, Monclús HA, Allende MT, et al. Modeling pharmacological inhibition of mast cell degranulation as a therapy for insulinoma. Neoplasia. 2011 Nov; 13(11): 1093-100.

78 Ryschich E, Autschbach F, Eisold S, Klar E, Buchler MW, Schmidt J. Expression of HLA class $\mathrm{I} / \mathrm{II}$ antigens and $\mathrm{T}$ cell immune response in human neuroendocrine tumors of the pancreas. Tissue Antigens. 2003 Jul;62(1): 48-54.

79 Katsenelson NS, Shurin GV, Bykovskaia SN, Shogan J, Shurin MR. Human small cell lung carcinoma and carcinoid tumor regulate dendritic cell maturation and function. Mod Pathol. 2001 Jan;14(1):40-5.

80 Krug S, Abbassi R, Griesmann H, Sipos B, Wiese D, Rexin P, et al. Therapeutic targeting of tumor-associated macrophages in pancreatic neuroendocrine tumors. Int $\mathrm{J}$ Cancer. 2018 Oct;143(7):1806-16.

81 Pyonteck SM, Gadea BB, Wang HW, Gocheva V, Hunter KE, Tang LH, et al. Deficiency of the macrophage growth factor CSF-1 disrupts pancreatic neuroendocrine tumor development. Oncogene. 2012 Mar;31(11): 1459-67.

82 Wei IH, Harmon CM, Arcerito M, Cheng DF, Minter RM, Simeone DM. Tumor-associated macrophages are a useful biomarker to predict recurrence after surgical resection of nonfunctional pancreatic neuroendocrine tumors. Ann Surg. 2014 Dec;260(6): 1088-94.

83 Vikman S, Giandomenico V, Sommaggio R, Oberg K, Essand M, Tötterman TH. CD8+ T cells against multiple tumor-associated antigens in peripheral blood of midgut carcinoid patients. Cancer Immunol Immunother. 2008 Mar;57(3):399-409.

84 Tucci M, Stucci S, Passarelli A, Giudice G, Dammacco F, Silvestris F. The immune escape in melanoma: role of the impaired dendritic cell function. Expert Rev Clin Immunol. 2014 Oct;10(10):1395-404.

85 Alvarez MJ, Subramaniam PS, Tang LH, Grunn A, Aburi M, Rieckhof G, et al. A precision oncology approach to the pharmacological targeting of mechanistic dependencies in neuroendocrine tumors. Nat Genet. 2018 Jul; 50(7):979-89.

86 Kim ST, Ha SY, Lee S, Ahn S, Lee J, Park SH, et al. The Impact of PD-L1 Expression in Patients with Metastatic GEP-NETs. J Cancer. 2016 Feb;7(5):484-9.
87 Sampedro-Núñez M, Serrano-Somavilla A, Adrados M, Cameselle-Teijeiro JM, BlancoCarrera C, Cabezas-Agricola JM, et al. Analysis of expression of the PD-1/PD-L1 immune checkpoint system and its prognostic impact in gastroenteropancreatic neuroendocrine tumors. Sci Rep. 2018 Dec;8(1): 17812.

88 Bösch F, Brüwer K, Altendorf-Hofmann A, Auernhammer CJ, Spitzweg C, Westphalen $\mathrm{CB}$, et al. Immune checkpoint markers in gastroenteropancreatic neuroendocrine neoplasia. Endocr Relat Cancer. 2019 Mar 1;26(3): 293-301.

89 Cavalcanti E, Armentano R, Valentini AM, Chieppa M, Caruso ML. Role of PD-L1 expression as a biomarker for GEP neuroendocrine neoplasm grading. Cell Death Dis. 2017 Aug;8(8):e3004.

90 Saganas C, Blank A, Franzelli M, Marinoni I, Perren A. PD-L1 is expressed in a subset of pancreatic neuroendocrine tumours (pNET). 14th Annual ENETS conference 2017. 2017:Abstract 1780.

91 Fan Y, Ma K, Wang C, Ning J, Hu Y, Dong D, et al. Prognostic value of PD-L1 and PD-1 expression in pulmonary neuroendocrine tumors. OncoTargets Ther. 2016 Oct;9:607582.

92 Ohtaki Y, Kaira K, Atsumi J, Nagashima T, Kawashima O, Ibe T, et al. Prognostic significance of PD-L1 expression and tumor infiltrating lymphocytes in large cell neuroendocrine carcinoma of lung. Am J Transl Res. 2018 Oct;10(10):3243-53.

93 Salem ME, Puccini A, Grothey A, Raghavan D, Goldberg RM, Xiu J, et al. Landscape of Tumor Mutation Load, Mismatch Repair Deficiency, and PD-L1 Expression in a Large Patient Cohort of Gastrointestinal Cancers. Mol Cancer Res. 2018 May;16(5): 805-12.

94 Teng MW, Ngiow SF, Ribas A, Smyth MJ. Classifying cancers based on T-cell infiltration and PD-L1. Cancer Res. 2015 Jun;75(11): 2139-45.

95 Yao JC, Phan A, Hoff PM, Chen HX, Charnsangavej C, Yeung SC, et al. Targeting vascular endothelial growth factor in advanced carcinoid tumor: a random assignment phase II study of depot octreotide with bevacizumab and pegylated interferon alpha-2b. J Clin Oncol. 2008 Mar;26(8): 1316-23.

96 Yao JC, Guthrie KA, Moran C, Strosberg JR, Kulke MH, Chan JA, et al. Phase III Prospective Randomized Comparison Trial of Depot Octreotide Plus Interferon Alfa-2b Versus Depot Octreotide Plus Bevacizumab in Patients With Advanced Carcinoid Tumors: SWOG S0518. J Clin Oncol. 2017 May;35(15): 1695-703.

97 Raymond E, Dahan L, Raoul JL, Bang YJ, Borbath I, Lombard-Bohas C, et al. Sunitinib malate for the treatment of pancreatic neuroendocrine tumors. N Engl J Med. 2011 Feb; 364(6):501-13.
98 Zurita AJ, Khajavi M, Wu HK, Tye L, Huang $\mathrm{X}$, Kulke $\mathrm{MH}$, et al. Circulating cytokines and monocyte subpopulations as biomarkers of outcome and biological activity in sunitinib-treated patients with advanced neuroendocrine tumours. Br J Cancer. 2015 Mar;112(7):1199-205.

99 Phan AT, Halperin DM, Chan JA, Fogelman DR, Hess KR, Malinowski P, et al. Pazopanib and depot octreotide in advanced, well-differentiated neuroendocrine tumours: a multicentre, single-group, phase 2 study. Lancet Oncol. 2015 Jun;16(6): 695-703.

100 Grande E, Capdevila J, Castellano D, Teulé A, Durán I, Fuster J, et al. Pazopanib in pretreated advanced neuroendocrine tumors: a phase II, open-label trial of the Spanish Task Force Group for Neuroendocrine Tumors (GETNE). Ann Oncol. 2015 Sep;26(9): 1987-93.

101 Strosberg JR, Cives M, Hwang J, Weber T, Nickerson M, Atreya CE, et al. A phase II study of axitinib in advanced neuroendocrine tumors. Endocr Relat Cancer. 2016 May;23(5):411-8.

102 Bill R, Fagiani E, Zumsteg A, Antoniadis $H$, Johansson D, Haefliger S, et al. Nintedanib Is a Highly Effective Therapeutic for Neuroendocrine Carcinoma of the Pancreas (PNET) in the Rip1Tag2 Transgenic Mouse Model. Clin Cancer Res. 2015 Nov; 21(21):4856-67.

103 Xu JM, Wang Y, Chen YL, Jia R, Li J, Gong JF, et al. Sulfatinib, a novel kinase inhibitor, in patients with advanced solid tumors: results from a phase I study. Oncotarget. 2017 Jun;8(26):42076-86.

104 Sennino B, Ishiguro-Oonuma T, Wei Y, Naylor RM, Williamson CW, Bhagwandin $\mathrm{V}$, et al. Suppression of tumor invasion and metastasis by concurrent inhibition of c-Met and VEGF signaling in pancreatic neuroendocrine tumors. Cancer Discov. 2012 Mar; 2(3):270-87.

105 Chan JA, Faris JE, Murphy JE, Blaszkowsky LS, Kwak EL, McCleary NJ, et al. Phase II trial of cabozantinib in patients with carcinoid and pancreatic neuroendocrine tumors (pNET). J Clin Oncol. 2017; 35(4 suppl):228.

106 Harney AS, Karagiannis GS, Pignatelli J, Smith BD, Kadioglu E, Wise SC, et al. The Selective Tie2 Inhibitor Rebastinib Blocks Recruitment and Function of Tie2Hi Macrophages in Breast Cancer and Pancreatic Neuroendocrine Tumors. Mol Cancer Ther. 2017 Nov; 16(11):2486-501.

107 Kulke MH, Hörsch D, Caplin ME, Anthony LB, Bergsland E, Öberg K, et al. Telotristat Ethyl, a Tryptophan Hydroxylase Inhibitor for the Treatment of Carcinoid Syndrome. J Clin Oncol. 2017 Jan;35(1):14-23.

108 Rickman DS, Beltran H, Demichelis F, Rubin MA. Biology and evolution of poorly differentiated neuroendocrine tumors. Nat Med. 2017 Jun;23(6):1-10. 
109 Mehnert JM, Rugo HS, O'Neil BH, Santoro A, Schellens JHM, Cohen RB, et al. $4270-$ Pembrolizumab for patients with PD-L1positive advanced carcinoid or pancreatic neuroendocrine tumors: results from the KEYNOTE-028 study. Ann Oncol. 2017; 28(Suppl 5):v142-v157.

110 Yao JC, Strosberg J, Fazio N, Pavel ME, Ruszniewski P, Bergsland E, et al. 1308O Activity and safety of spartalizumab (PDR001) in patients with advanced neuroendocrine tumors of pancreatic, gastrointestinal or thoracic origin, \& gastroenteropancreatic neuroendocrine carcinoma who have progressed on prior treatment. Ann Oncol. 2018;29(Suppl 8):viii467-viii478.
111 Yu D, Leja-Jarblad J, Loskog A, Hellman P, Giandomenico V, Oberg K, et al. Preclinical Evaluation of AdVince, an Oncolytic Adenovirus Adapted for Treatment of Liver Metastases from Neuroendocrine Cancer. Neuroendocrinology. 2017;105(1):54-66.

112 Levra MG, Mazieres J, Valette CA, Molinier O, Planchard D, Frappat V, Ferrer L, Toffart AC, Moro-Sibilot D. P1.07-012. Efficacy of immune checkpoint inhibitors in large cell neuroendocrine lung cancer: results from a French retrospective cohort. J Thoracic Oncol. 2017;12(Suppl 1):S702-3.
113 Horn L, Mansfield AS, Szczęsna A, Havel L, Krzakowski M, Hochmair MJ, et al.; IMpower133 Study Group. First-Line Atezolizumab plus Chemotherapy in Extensive-Stage Small-Cell Lung Cancer. N Engl J Med. 2018 Dec;379(23):2220-9.

114 Ugwu JK, Nwanyanwu C, Shelke AR. Dramatic Response of a Metastatic Primary Small-Cell Carcinoma of the Pancreas to a Trial of Immunotherapy with Nivolumab: A Case Report. Case Rep Oncol. 2017 Aug; 10(2):720-5.

115 Schmidt D, Wiedenmann B. Extremely Long Survival under Combined Immunotherapy in a Metastatic Functional Neuroendocrine Neoplasia Patient. Neuroendocrinology. 2018;106(4):381-8 